\title{
MEASUREMENT OF REGIONAL INNOVATION SYSTEMS' CAPABILITIES THROUGH UNIVERSITY-INDUSTRY (UI) INTERACTIONS: A CASE STUDY FOR BRAZILIAN CITIES
}

\author{
Thiago Caliari, Dr. \\ Applied Social Sciences Institute \\ Federal University of Alfenas - UNIFAL \\ thiago.caliari@unifal-mg.edu.br \\ Márcia Siqueira Rapini, Dra. \\ Center for Regional Development and Planning (CEDEPLAR- UFMG) \\ msrapini@cedeplar.ufmg.br \\ Deive Ciro de Oliveira, Dr. \\ Applied Social Sciences Institute \\ Federal University of Alfenas - UNIFAL \\ deive.oliveira@unifal-mg.edu.br \\ Jéssica Felix da Silva \\ Applied Social Sciences Institute \\ Federal University of Alfenas - UNIFAL \\ jessica.felix92@gmail.com
}

\begin{abstract}
This paper investigates the university-firm knowledge flow in Brazilian cities in order to infer the regional capacity to attract interaction from outside. The Directory of Research group database from Censo 2008 was used in municipal level. Using maps of knowledge flow, a coefficient of interactivity and a cluster analyses we were able to identify the knowledge flow among Brazilian Regions. The results corroborate previous studies about Brazilian regional concentration regarding science and technology, but also show a relative deconcentration with importance to other cities than the traditionally highlighted. Despite the limitations, we understand that using U-I interaction flows to measure innovative capacity of regions may be an interesting methodology that should be better developed.
\end{abstract}

Key-words: university-industry interactions, knowledge flow, research groups, Brazilian cities.

\section{RESUMO}

Esse artigo investiga os fluxos de conhecimento na interação universidade-empresa como uma forma de medir a capacidade dos sistemas regionais de inovação de cidades brasileiras. Para tal foi utilizado o Diretório dos Grupos de Pesquisa do CNPq, censo 2008. Usando mapas de fluxo de conhecimento, um coeficiente de interatividade e análise de clusters pudemos identificar as particularidades dos municípios do Brasil. Os resultados corroboram demais estudos sobre a concentração em ciência e tecnologia nas regiões brasileiras, mas também aponta uma desconcentração relativa com importância para demais cidades que não as tradicionalmente destacadas. Apesar das limitações, entendemos que analisar a capacitação regional em C\&T através das interações U-E é uma metodologia interessante e que deve ser melhor desenvolvida.

Palavras-chave: interação universidade-empresa, fluxos de conhecimento, grupos de pesquisa, municípios do Brasil.

JEL: O3, R1 


\section{INTRODUCTION}

In the 90s it was established the concept of Regional Innovation Systems (RIS) (COOKE, 1998; OINAS; MALECKI, 1999). At this perspective, the importance of regional specificities is considered in the economic, social, political and geographical focus. So, in a historical perspective, it is relevant the understanding of how regional agents interact to achieve regional economic development (GRANOVETER, 1985).

Different studies uses distinct geographical boundaries and different indicators for S,T\&I, economic and social issues to mark the development of RIS. There are quantitative analysis using patents and scientific papers database (NARIN et al, 1997; ALBUQUERQUE et al, 2002; GONÇALVES and ALMEIDA, 2009), the measurement of economic and innovative potential at regional level (FRITSCH, 2002; LEYDESDORFF \& FRITSCH, 2006; SANTOS \& CALIARI, 2012), regions analyses by sectoral/regional case studies (MAIA, 2005; LENGYEL \& LEYDESDORFF, 2010; SANTOS, 2012) and the interaction between universities and firms (JAFFE, 1989; JAFFE et al, 1993; MANSFIELD, 1995; GARCIA et al, 2014; CALIARI \& RAPINI, 2016).

In a RIS perspective, it is important to highlight the relationships between (i) the internal agents (FLORIDA, 1995) and (ii) the inner knowledge (science and technology) and new technical and scientific knowledge generated in other innovative environments that allow improvements in local innovative production (OINAS and MALECKI, 1999; MYTELKA and FARINELLI, 2003). At this aim, the interaction between universities and the industry (UI interaction) is a widely used strategy to measure innovative and scientific capacity.

It is reiterated in the literature that proximity has particular impact on knowledge transmission in UI interactions (BRENNER, 2001). Because of aspects related to tacit knowledge and to informal communication (PAVITT, 1998), the interactions of these agents in geographic proximity is an important element for RIS relevance (FLORIDA, 1995).

Nevertheless, often the regional proximity is not a sufficient condition for UI interaction. In many cases it is usual that a firm searches knowledge of more distant universities/research institutes. There are various determinants for these types of interactions, but among those one that are most highlighted is the universities/research institutes excellence (MARIANI, 2004; MANSFIELD, 1995; MAIA, 2005; LAURSEN et al, 2011; GARCIA et al, 2014; CALIARI \& RAPINI, 2016).

Thus, besides the relevance of internal interactions inside RIS, the scientific expertise of universities in providing solutions to firms located far from RIS could be another indicative of RIS capacity. In short, an profitable environment for S,T\&I improvement may reflect into internal interactions but also on the capacity of scientific institutions in generating external interactions with firms outside the RIS. So, a relative analysis of internal and external interactions of scientific agents from one RIS may contribute to the quantitative measurement of the innovation systems' capabilities at a regional level.

On this perspective, this paper considers data related to university-firm interactions from Census 2008 of the Directory of Research Groups in Brazil, especially regarding regional flows of interactions among universities and firms. Some statically procedures and a cluster analyses were proposed to identify the knowledge flow between Brazilians regions.

Beyond this introduction the article is organized in 5 more sections. Section 2 is a literature review concerning university-firms interactions focused in knowledge flow and the importance of local proximity for innovation. Section 3 present the Directory of Research Group database regarding U-I knowledge flow in Brazilian cities. Sections 4 and 5 presents different methodologies to analysis the database: maps of knowledge flow, a coefficient of 
interactivity and a cluster analyses. Section 6 summarizes the results found in the previews analyses.

\section{2 - REGIONAL INNOVATION SYSTEM AND UNIVERSITY-FIRMS KNOWLEDGE FLOW}

The Regional Innovation System (RIS) concept was inspired by the National Innovation System approach, despites, the importance of the region were already emphasized by the success of regional and industrial clusters and district of post-fordist era. The concept was first published by Cooke in 1992 and embracing the following aspects: a) the importance of the regions as the focus of global economic competitiveness to firms; b) the importance of setting routines, rules and institutional norms in a region; c) formal and informal networks and support mechanisms for high-trust relationships, important to minimize the transaction costs between firms; d) the importance of geographical proximity to facilitate the exchange of innovative tacit knowledge and other externalities; and e) recognition of the importance of an institutional and organizational learning environment conducive to regional economic development.

The regional innovation system can be defined as the support infrastructure innovation in the productive structure of the region. To Granoveter (1985) a Regional Innovation System is an environment related to social embeddedness of firm and agents in the same local, social and economic context, which would allow its economic and innovative success through building bridges to the transmission of knowledge among agents.

The innovative capacity of a geographical area, therefore, is the result of historical events that determine the region growth trajectory (ARTHUR, 1990). The co-location of complementary resources provides economies of scope that benefit the innovation and commercialization of new products. The complementary institutions of technological infrastructure provide resources and expertise to the innovative process, generating positive externalities and spillovers which reduce the cost of marketing new products, and the risks associated with innovation (FELDMAN, 1994).

Local capacities in a region are based on its infrastructure, access to natural resources, in particular institutional environment, human resources and in available techniques and experiences. The institutional endowment is the transmission of the stock of accumulated knowledge being created, transformed and eroded and re-created by the economic history of the region, creating each time a different type of knowledge. His interaction with the physical and human resources and local infrastructure lead to the creation of local capacity, which influence the competitiveness of firms located there (MASKELL AND MALMBERG, 1999).

Brenner (2000) summarizes the main interactions in RIS: a) firms in the same industry or related industry and same supply chain; b) labour market; c) Capital markets; d) Universities and research institutions; and e) Policy. For these interactions to create additional economic activity, it is required some accumulative process, where the increase in one variable increases other variables exerting positive effect on the first variable (positive feedback loops).

The interaction with universities and research institutes are one of the relevant interactions. Universities are responsible for labor education, training and updating. Academic research contributes to the solution of problems in firms (KLEVORICK et al., 1995) and to the development of new techniques and instruments (ROSENBERG, 1992). The transmission of knowledge generated in universities to firms can occur via scientific publications, $R \& D$ or informal formal cooperation in carrying out $R \& D$ contracts. The transmission of tacit scientific knowledge, in particular, is enhanced with the proximity between universities and 
research institutions and firms. Universities also contribute as external source of input knowledge to create new spin-off firms.

The tacit knowledge is recognized as the principal determinant for geographical proximity in innovation as its central to the interactive learning process. For university-firms interactions it has particular impact as its transmission requires previous contacts and experiences. Therefore, absorption of scientific knowledge, particularly tacit nature, varies terms of business structure, industrial sector and present institutions. Geographical proximity itself although necessary, is not sufficient for the existence of interactions that lead to the transmission of knowledge. Other factors such as economies of knowledge codification, labor market and acquisition strategies also explain the location of the phenomenon (BRESCHI \& LISSONI, 2001).

In many cases it is usual that a firm with absorptive capacity can searches knowledge of more distant universities/research institutes. There are various determinants for these types of interactions, but among those one that are most highlighted is the universities/research institutes excellence (MARIANI, 2004; MANSFIELD, 1995; MAIA, 2005; LAURSEN et al, 2011; GARCIA et al, 2014; CALIARI \& RAPINI, 2016).

Some studies based in Brazilian framework show uneven regional science and technology capabilities.

Albuquerque et. al (2002) using article (in 1999), researchers (in 2000) and patent (1990 to 2000) database in municipal level also found concentration in science and technology capabilities in Central-South Brazilian regions. Scientific and technological concentration are also inclusive higher than the productive concentration (measured in employment in industry in 1999), a result different from the north-American case, as an example. Comparing the Brazilian states, São Paulo shows the lower innovative concentration coefficient and also a highest complementary capacity with its surroundings.

Santos and Caliari (2012) analyzed the structures for support innovation in Brazilian fifty largest micro-regions in 2003 and 2008, as a proxy to regional innovation system. They found a strong concentration of this structure in a small group of regions, and also a strong association between variables linked to economic development and those related to technological structure these micro-regions. São Paulo micro-region shows a different and a higher technological pattern, and the other regions showed little change between periods.

Gonçalvez and Farjado (2011) used patents appliance between 1999-2001 to Brazilian geographical mesoregion and special econometric techniques, organized in four technological clusters: chemical and bio-pharmaceutical, new materials, mechanical and process technologies and electrical and electronic technologies. They found a concentrated regional pattern of technological activities in few Brazilian mesoregions. In all technological clusters São Paulo, Campinas, Piracicaba and Curitiba mesoregions appear recurrently. In new materials and electronic technologies Florianópolis and Manaus also stands outs, respectively.

The results corroborate previous studies as Diniz and Gonçalves (2001) that establish three major regions in terms of technological innovation. The first, called "Dynamic Region" that has a network of urban and integrated cities with good conditions for expansion and economic modernization. The "Empty Region" defined by the Midwest and North Regions, established as a major producer of agricultural and mineral commodities. The "Late Region" is composed of the Northeast that remains as a less potential to technological development, despite of having "islands" of technological production.

Gonçalvez and Farjado (2011) also found the importance of employment density and university research to determine Brazilian technological activity. They found that not only geographical proximity but also technological similarity of the regions exercises a decisive 
effect on the generation of innovations. This result indicates that innovation in mesoregion is positively influenced by technological activity from neighboring mesoregions.

Casali et. al (2010) used data regarding total and industrial GDP, R\&D, patents, productivity and the use of electrical light in industry from 1990 to 2005 and econometric models to infer the technological gap among Brazilian regions. They found that the variable with the highest power to influence the GDP, both at regional and at the state level is productivity, that is, the ability to absorb innovations. The development of new technologies (proxy as patent) was also significant although it had a lower impact on regions and states GDP. The adoption of new technologies incorporated in machinery and equipment (proxy as electricity consumption) exerts considerable influence in industrial GDP (but not in total GDP). Although less developed regions are not making an effort to technological development, they can match their productivity relative to that existing in the Southeast, by an imitating technological process. They highlight the importance of North, Northeast and Central Region to start its own research to economic and technological development.

\section{3 - MATERIAL AND METHODS}

This work uses the database 'Directory of Research Groups' (DRG) available by the National Council for Scientific and Technological Development (CNPq). The data are from Census 2008. The DRG database is the inventory of active research groups in Brazil and it congregates information about human resources, scientific and technological production and knowledge areas, among others. These groups are located in universities, scientific research institutes, technological institutes, $\mathrm{R} \& \mathrm{D}$ firm labs and non-governmental organizations. Besides that, the DRG presents information about research groups that establish interactions with firms, being the more widely information set regarding UF interaction available in Brazil $^{1}$.

Considering the importance of interactions to understand regional system of innovation, the DRG database was used to access information about research groups and their interaction with firms. The data were categorized by cities (the considered regional cut) and they were treated for different methods of analysis as a way to establish relative comparison. Interaction flow maps were used to show the regional distribution of U-I knowledge flow and a coefficient of interactivity was constructed, based on location quotient's idea, to understand the relative capacity of cities in doing U-I interactions. The techniques and results are presented in the next subsections.

\section{4 - INTERACTION FLOW MAPS}

Firstly it is presented a flow map of interactions among cities ${ }^{2}$. The direction of interaction is represented in colored markings through a connection line. The interaction flow follows the university $\rightarrow$ firm direction, which means that the interaction comes from university (outflow) to the firm (inflow). Considering, for example, the following figure about a university located in city $X$ and a firm located in city $Y$ :

\footnotetext{
${ }^{1}$ However, DRG is the result of voluntary information provided by the research group leaders. So, it does not represents all the existing UF interactions in the country.

2 The flow maps were created using JflowMap (online at: https://code.google.com/archive/p/jflowmap/. Access in 03-2016).
} 


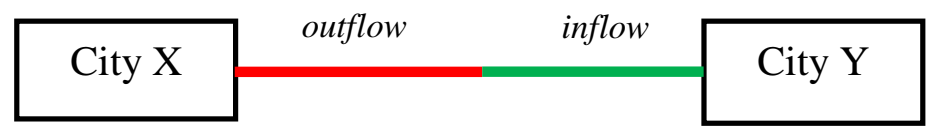

Figure 1: Flow Interaction

Source: Own elaboration.

Thus, the city where the university is located has an outflow direction which is represented by a red color line; at the other side, the city where the firm is located has an inflow direction and it is represented by the extension of the same line, but now in a green color way. It is worth to note that, despite the example is representing just a single interaction, the same consideration applies to the observation of the net sum of interactions between cities. So, if these counties perform $n$ interactions, the net result will be the same as the above figure if the city $X$ has $[(n+1) / 2]$ outflows in relation to the city $Y$. In addition, interactions within a city are represented as a yellow circle.

It is implemented the bundling algorithm proposed by Holten (2009) in which "the flows are visually bundled along their joint paths, which are often strapped together in bundles" (BOYANDIN et al, 2010). Edges are modeled as flexible springs that can attract each other while node positions remain fixed. So, a force-directed technique is used to calculate the bundling. The resulting graphs show significant clutter reduction and clearly visible high-level edge patterns, retaining only what is desirable.

This procedure is an initial measure to capture in a graphical representation the relative capabilities of cities in respect of their innovation systems. At this time it is being considered that besides the relevance of internal interactions inside RIS, the scientific expertise of universities in providing solutions to firms located far from RIS could be another indicative of RIS capacity. In short, an profitable environment for S,T\&I improvement may reflect into internal interactions but also on the capacity of scientific institutions in generating external interactions with firms outside the RIS.

The results are presented at Figure 2 and 3 below. The first one is about Brazil and the second one is about some important regional cuts. There were 6558 interactions between research groups and firms in 2008. These interactions are made by 2920 research groups located in 225 different cities. Still, there were 23793 research groups in 378 cities. It shows that Brazilian scientific capacitation is concentrated: just 6,79\% of the total of Brazilian cities (5563 cities) had research groups in 2008 and just 4,04\% had interactive research groups. Still, $12,27 \%$ of the research groups in DGP database were interactive groups.

Regarding productive sector, 4419 firms located in 840 cities performed U-I interactions. It means that if some firms want to interact, they have to do that with research groups located in another city. This specificity is expressed also in the intense flow of interactions among distinct cities. 
Figure 2: Flow map of U-I interactions in Brazil, 2008.
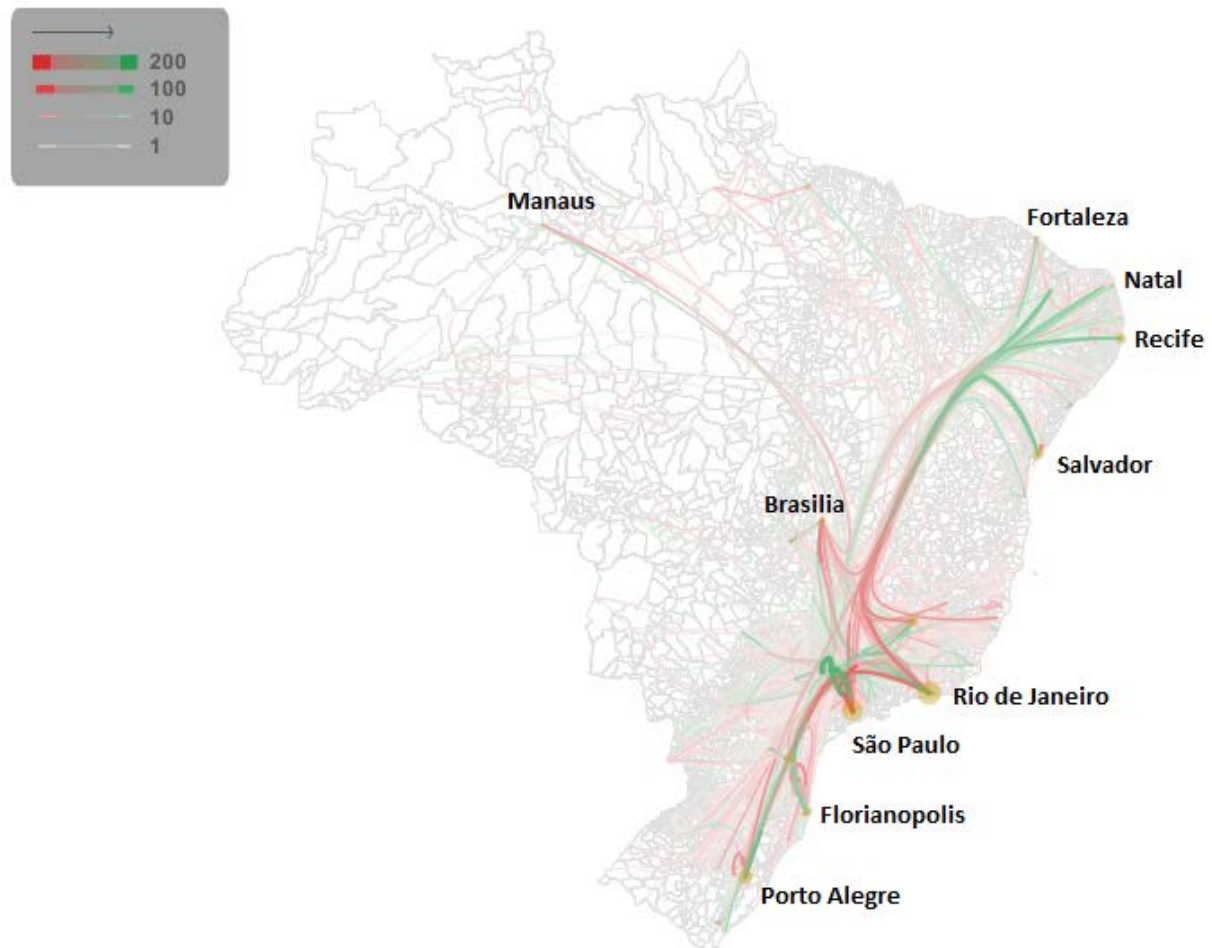

Source: Author's own elaboration. 


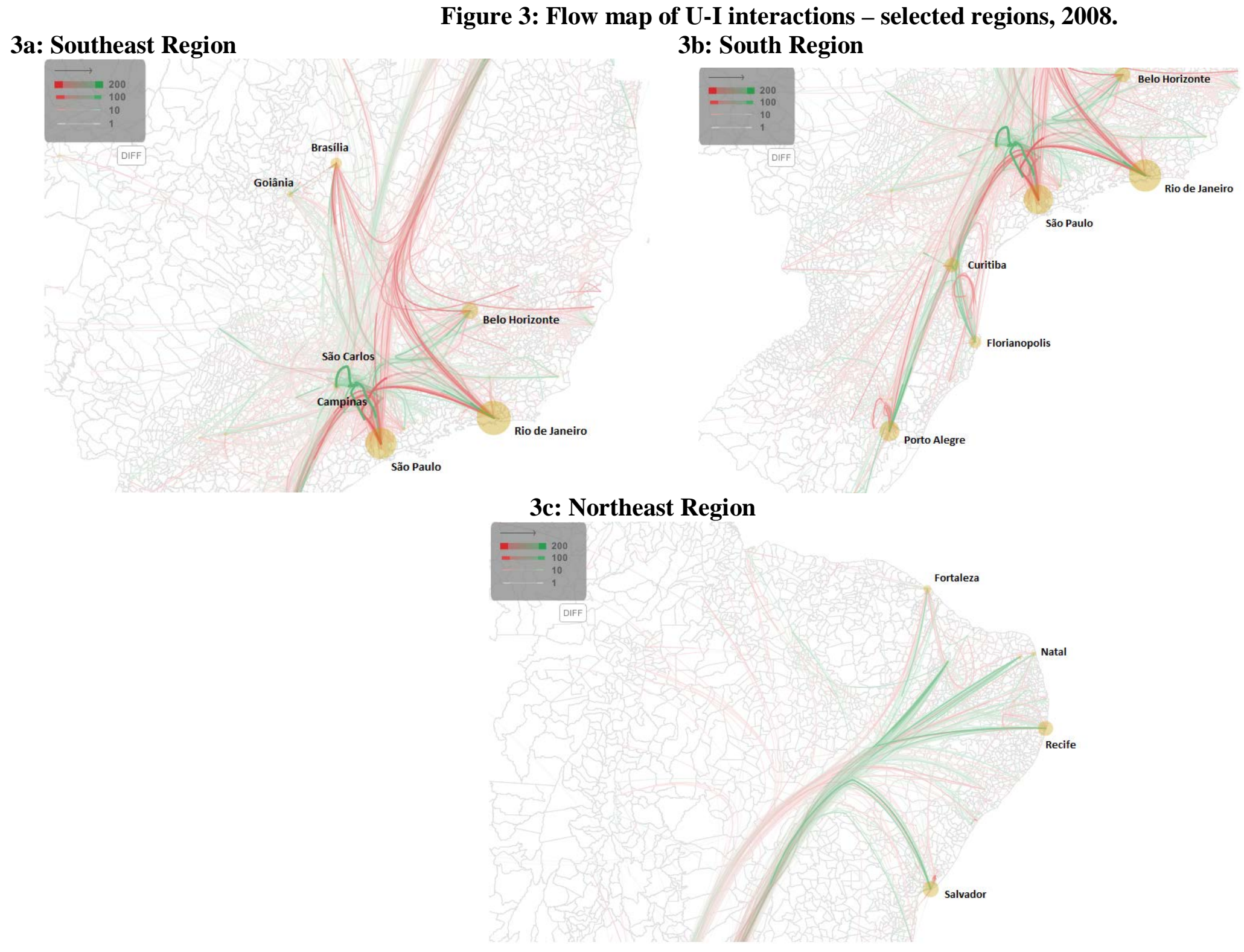


Some results may be pointed out. There is a concentration of interactions on the coastal axis, connecting mainly cities of Southeast region, Northeast Region and South Region. Besides, the internal state distribution points out to the relevance of capitals and economic centers.

It can also be noted the predominance of relevant universities in Southeast Region in national scale. In a general view, cities in the Southeast Region - plus Brasilia, the national capital - have liquid positive knowledge flow against the Northeast Region. It indicates the importance of universities and research institutes in this federative region to provide knowledge. Caliari and Rapini (2016) found that research groups in the regions South, North and Northeast interact at greater distances than research groups in the Southeast Region. We found graphically that this interactive dynamic is explained as research groups in the Southeast Region provide a knowledge base for firms in other regions.

Figure 3 shows remarked finding. The two major economic cities in Brazil (São Paulo and Rio de Janeiro), also located in the Southeast Region, have a considerable number of interactions within the RIS, which is represented by the yellow circle. In addition, some other cities present a relevant internal scale of interactions as Porto Alegre, Curitiba, Florianopolis, Belo Horizonte, Salvador, Recife, Fortaleza, Natal and Brasilia.

Other cities also present interesting interaction flows. Agents in São Carlos and surrounding cities have an important number of interactions with agents located in Campinas and São Paulo. The flow found in this geographic area points out to the relevance of considering regional innovation systems on a larger geographical scale, at least for this cut.

These findings are best viewed in the Table 1 which presents the main interaction flows highlighting some important features from those ones.

Table 1: Main interaction flows

\begin{tabular}{|c|c|c|c|c|c|c|}
\hline Research Group city & $\begin{array}{c}\text { RG } \\
\text { State }\end{array}$ & Firm City & Firm state & Interactions & $\begin{array}{l}\% \text { of } \\
\text { total }\end{array}$ & $\begin{array}{c}\text { Cumulative } \\
\%\end{array}$ \\
\hline 1. Rio de Janeiro & RJ & Rio de Janeiro & RJ & 272 & $4,15 \%$ & \\
\hline 2. São Paulo & SP & São Paulo & SP & 248 & $3,78 \%$ & $7,93 \%$ \\
\hline 3. Porto Alegre & RS & Porto Alegre & RS & 170 & $2,59 \%$ & $10,52 \%$ \\
\hline 4. Salvador & BA & Salvador & BA & 135 & $2,06 \%$ & $12,58 \%$ \\
\hline 5. Belo Horizonte & MG & Belo Horizonte & MG & 130 & $1,98 \%$ & $14,56 \%$ \\
\hline 6. Recife & $\mathrm{PE}$ & Recife & $\mathrm{PE}$ & 127 & $1,94 \%$ & $16,50 \%$ \\
\hline 7. Curitiba & PR & Curitiba & PR & 123 & $1,88 \%$ & $18,37 \%$ \\
\hline 8. Florianopolis & SC & Florianopolis & SC & 105 & $1,60 \%$ & $19,98 \%$ \\
\hline 9. Brasília & DF & Brasília & DF & 91 & $1,39 \%$ & $21,36 \%$ \\
\hline 10. Fortaleza & CE & Fortaleza & $\mathrm{CE}$ & 67 & $1,02 \%$ & $22,38 \%$ \\
\hline 11. Belém & PA & Belém & PA & 61 & $0,93 \%$ & $23,32 \%$ \\
\hline 12. São Carlos & SP & São Paulo & SP & 55 & $0,84 \%$ & $24,15 \%$ \\
\hline 13. São Carlos & SP & São Carlos & SP & 53 & $0,81 \%$ & $24,96 \%$ \\
\hline 14. Goiânia & GO & Goiânia & GO & 50 & $0,76 \%$ & $25,72 \%$ \\
\hline 15. Campinas & SP & São Paulo & SP & 49 & $0,75 \%$ & $26,47 \%$ \\
\hline 16. Natal & $\mathrm{RN}$ & Natal & $\mathrm{RN}$ & 44 & $0,67 \%$ & $27,14 \%$ \\
\hline
\end{tabular}




\begin{tabular}{l|l|l|l|l|l|l} 
17. Manaus & AM & Manaus & AM & 43 & $0,66 \%$ & $27,80 \%$ \\
\hline 18. Rio de Janeiro & RJ & São Paulo & SP & 41 & $0,63 \%$ & $28,42 \%$ \\
\hline 19. Santa Maria & RS & Santa Maria & RS & 38 & $0,58 \%$ & $29,00 \%$ \\
\hline 20. Caxias do Sul & RS & Caxias do Sul & RS & 34 & $0,52 \%$ & $29,52 \%$ \\
\hline 21. Londrina & PR & Londrina & PR & 31 & $0,47 \%$ & $29,99 \%$ \\
\hline 23. Pelotas & RS & Pelotas & RS & 30 & $0,46 \%$ & $30,45 \%$ \\
\hline 24. São José dos Campos & RS & Rio de Janeiro & RJ & 29 & $0,44 \%$ & $30,89 \%$ \\
\hline 25. Cuiabá & São José dos Campos & SP & 29 & $0,44 \%$ & $31,34 \%$ \\
\hline 26. Campinas & Cuiabá & MT & 28 & $0,43 \%$ & $31,76 \%$ \\
\hline 27. Viçosa & SP & Campinas & SP & 27 & $0,41 \%$ & $32,17 \%$ \\
\hline 28. Maringá & MG & Viçosa & MG & 25 & $0,38 \%$ & $32,56 \%$ \\
\hline 29. Juiz de Fora & PR & Maringá & PR & 24 & $0,37 \%$ & $32,92 \%$ \\
\hline 30. Porto Alegre & MG & Juiz de Fora & MG & 23 & $0,35 \%$ & $33,27 \%$ \\
\hline 31. Rio Grande & RS & São Paulo & SP & 23 & $0,35 \%$ & $33,62 \%$ \\
\hline 32. Uberlandia & RS & Rio Grande & RS & 23 & $0,35 \%$ & $33,97 \%$ \\
\hline 33. Rio de Janeiro & MG & Uberlandia & MG & 23 & $0,35 \%$ & $34,32 \%$ \\
\hline 34. Campina Grande & RJ & Brasília & DF & 22 & $0,34 \%$ & $34,66 \%$ \\
\hline 35. Curitiba & PB & Campina Grande & PB & 21 & $0,32 \%$ & $34,98 \%$ \\
\hline 36. Salvador & PR & São Paulo & SP & 21 & $0,32 \%$ & $35,30 \%$ \\
\hline 37. Campos Goytacazes & BA & Rio de Janeiro & RJ & 21 & $0,32 \%$ & $35,62 \%$ \\
\hline & RJ & Campos Goytacazes & RJ & 20 & $0,30 \%$ & $35,93 \%$ \\
\hline
\end{tabular}

Source: Own elaboration.

The table presents cities with more than 20 interactions between universities and firms. These 37 interaction flows corresponds to almost $36 \%$ of the total of U-I interactions. The result corroborates results regarding concentration of the interactions, already highlighted in previous paragraphs. Besides that, 29 of these 37 interactions were made inside a city, which corroborates the influence of proximity on U-I interactions (as in GARCIA et al, 2014; CALIARI and RAPINI, 2016, among others).

The importance of major capital cities is again checked in the total of internal interactions, but it can be added other cities with relevant interaction flows:

1. Southeast region: São Carlos, Campinas, São José dos Campos, Viçosa, Juiz de Fora and Campos dos Goytacazes;

2. South region: Santa Maria, Caxias do Sul, Londrina, Pelotas and Rio Grande;

3. Northeast region: Campina Grande;

4. Midwest region: Goiânia and Cuiabá;

5. North region: Belém and Manaus.

These observations do not exhaust, however, the existence of other cities in these regions with a large number of interaction flows, even if lower than the cutting set of twenty interactions. Nevertheless, this result shows that beyond the importance of economic centers in establishing U-I interactions, the presence of a federal institution of higher education is an important factor to a city to perform U-I interactions. All cities quoted above have federal universities and the interactive research groups are predominantly composed of researchers who work in these universities. 
So, these findings highlight the influence of the knowledge generation in two major economic cities - São Paulo and Rio de Janeiro - for firms located in other states, as can be seen in the maps of interaction flows. But it also shed lights to the regional relevance of others interactions in relevant regional economic centers and cities with federal universities, who provide knowledge for firms located within their cities (or in a small geographic distance).

Considering that, the next analysis will do a relative comparison between all cities with interactive research groups and firms, taking account their scientific and economic structures.

\section{5 - THE COEFFICIENT OF INTERACTIVITY (CI )}

The previous analysis considers the total amount of interactions in each city. Now we suggested a way to measure the relative efficiency of the research groups and firms of a city to engage in interactions. It will be called as Coefficient of Interactivity $(C I)$ and it is composed by the relative capacity of research groups to engage in interactions with firms and the relative capacity of firms to engage in interactions with research groups, both at the municipal level.

Consider $\mathrm{CI}_{r g}$ and $\mathrm{CI}_{f}$ as Coefficient of Interactivity of Research Groups and Coefficient of Interactivity of firms, respectively. So:

(1) $C I=C I_{r g}+C I_{f}$

(2) $C I_{r g}^{i}=\frac{\frac{\sum_{i} r g_{i}^{i n t}}{\sum_{i} r g_{i}}}{\frac{\sum_{*} r g_{*}^{i n t}}{\sum_{*} r g_{*}}} \cdot\left(\frac{\sum_{i} r g_{i}^{i n t}}{\sum_{*} r g_{*}^{\text {int }}}\right)$

(3) $C I_{f}^{i}=\frac{\frac{\sum_{i} f_{i}^{i n t}}{\sum_{i} l_{i}}}{\frac{\sum_{*} f_{*}^{i n t}}{\sum_{*} l_{*}}} \cdot\left(\frac{\sum_{i} f_{i}^{i n t}}{\sum_{*} f_{*}^{i n t}}\right)$

For $C I_{r g}^{i}$ we have:

- $r g_{i}$ is the number of research groups in city $i$;

- $r g_{i}^{i n t}$ is the number of interactive research groups in city $i$;

- $r g_{*}$ is the total amount of research groups at country;

- $r g_{*}^{\text {int }}$ is the total amount of interactive research groups at country.

For $C I_{f}^{i}$ we have:

- $f_{i}^{i n t}$ is the number of interactive firms in city $i$;

- $f_{*}^{\text {int }}$ is the total amount of interactive firms at country;

- $l_{i}$ is the total number of employees in mining, manufacturing and agriculture sectors at city $i$;

- $l_{*}$ is the total number of employees in mining, manufacturing and agriculture sectors at country. 
The Coefficient of Interactivity $(C I)$ follows the Location Quotient's idea, but the implicit aim here is to capture the relative efficiency of regional institutions on UF interactions against the national capabilities controlling for relative share of municipal interactions. This control is important because the relative scale of interactive scientific and technological agents is an important measure when comparing regional innovation systems.

For the case of $\mathrm{CI}_{f}^{i}$ it is used the number of employees in productive sectors (mining, manufacturing and agriculture) as a proxy to the total number of productive firms (at city and national view). It proved necessary because there is no information about the total amount of all productive firms at municipal level in the database. The information about employees is from Annual Relation on Social Information (RAISIBGE).

After that, the Cluster Analysis is applied on the $C I$ as a way to capture similarities among cities, classifying those according homogeneity degrees. There are many methods for hierarchical clustering. In this paper the kmeans method is used, which considers the transfer of an individual (city) to the cluster whose centroid is in the shortest distance. Its input parameter is the cluster number $K$, dividing the set of $N$ elements in $K$ groups. The distance measure applied was the square of the Euclidean distance. After that, the dendogram graphic was useful to identify the choice on the final number of clusters ${ }^{3}$. There were chosen the number of clusters equal to $K=4$.

A view about the coefficient of interactivity $\left(C I, C I_{r g}\right.$ and $\left.C I_{f}\right)$ is presented below with the classification in clusters (only clusters 1 to 3 were presented in the Table below). It is also presented city positions in Table 1 to express comparability, but only when it was developed an internal interaction (university and firm at the same city). A total of 845 cities have $C I>0$ (which means that they have one interactive research group or one interactive firm, at least), $15.18 \%$ of the total of cities in Brazil.

Table 2 - Coefficient of Interactivity and Cluster Analysis

\begin{tabular}{|c|c|c|c|c|c|c|c|}
\hline $\mathbf{N}$ & State & City & $C I$ & $C I_{f}$ & $C I_{r g}$ & $\begin{array}{c}\text { Position } \\
\text { in Table } \\
1\end{array}$ & Cluster \\
\hline 1 & SC & Florianopolis & 0,740 & 0,049 & 0,691 & 8 & 4 \\
\hline 2 & RS & Porto Alegre & 0,310 & 0,068 & 0,243 & 3 & \multirow{5}{*}{3} \\
\hline 3 & RJ & Rio de Janeiro & 0,260 & 0,066 & 0,194 & 1 & \\
\hline 4 & $\mathrm{BA}$ & Salvador & 0,237 & 0,046 & 0,190 & 4 & \\
\hline 5 & $\mathrm{DF}$ & Brasilia & 0,223 & 0,026 & 0,198 & 9 & \\
\hline 6 & SP & São Paulo & 0,210 & 0,046 & 0,165 & 2 & \\
\hline 7 & $\mathrm{PE}$ & Recife & 0,135 & 0,046 & 0,089 & 6 & \multirow{8}{*}{2} \\
\hline 8 & MG & Belo Horizonte & 0,117 & 0,039 & 0,078 & 5 & \\
\hline 9 & MG & Vicosa & 0,115 & 0,054 & 0,061 & 27 & \\
\hline 10 & PR & Curitiba & 0,114 & 0,056 & 0,058 & 7 & \\
\hline 11 & RS & Santa Maria & 0,095 & 0,020 & 0,075 & 19 & \\
\hline 12 & SP & Jardinopolis & 0,091 & 0,000 & 0,091 & & \\
\hline 13 & MG & Lagoa Santa & 0,091 & 0,000 & 0,091 & & \\
\hline 14 & $\mathrm{~PB}$ & São Joao do Cariri & 0,087 & 0,000 & 0,087 & & \\
\hline
\end{tabular}

\footnotetext{
${ }^{3}$ We suggest Mingotti (2005) for more information about Cluster Analysis. The statistical software used
} is Stata 12. 


\begin{tabular}{l|c|l|c|c|c|c|}
15 & SP & Rio Claro & 0,080 & 0,003 & 0,076 & \\
\hline 16 & SP & São Carlos & 0,075 & 0,029 & 0,045 & 13 \\
\hline 17 & PB & Boqueirao & 0,064 & 0,000 & 0,064 & \\
\hline 18 & SP & Barra Bonita & 0,062 & 0,000 & 0,062 & \\
\hline 19 & TO & Palmas & 0,058 & 0,004 & 0,054 & \\
\hline 20 & SP & Campinas & 0,058 & 0,021 & 0,037 & 15 \\
\hline 21 & PA & Belem & 0,057 & 0,021 & 0,036 & 11 \\
\hline 22 & RS & Pelotas & 0,054 & 0,012 & 0,042 & 22 \\
\hline 23 & GO & Goiania & 0,051 & 0,028 & 0,023 & 14 \\
\hline 24 & PE & Primavera & 0,048 & 0,000 & 0,048 & \\
\hline 25 & BA & Teofilandia & 0,047 & 0,000 & 0,047 & \\
\hline 26 & SE & Santana do São & 0,044 & 0,000 & 0,044 & \\
\hline 27 & FE & Fortaleza & 0,044 & 0,021 & 0,023 & 10 \\
\hline 28 & MG & Pingo d'agua & 0,039 & 0,000 & 0,039 & \\
\hline 29 & RN & Natal & 0,038 & 0,015 & 0,023 & 16 \\
\hline
\end{tabular}

Source: Own elaboration.

Most of cities with internal interactions in Table 1 still are presented in Table 2, which shows that results regarding internal scale and efficiency of interactions are closely related. However, the positions differ: now Florianopolis is considered the main city in relative efficiency of interactions and can be defined as an outlier. This result is mainly due to the large number of interactions established by firms located there, even though it has a small number of employees in relation to the total national amount (high $\left.C I_{f}\right)$.

It can still be noted a core of 6 cities with values for $C I$ a bit higher compared to others; these cities belongs to cluster 1 - Florianopolis - and cluster 2 - Porto Alegre, Rio de Janeiro, Salvador, Brasília e São Paulo.

Some cities have no scientific competence to interact $\left(C I_{r g}=0\right)$, but they have firms with relative efficiency to find research groups in other places. Because of that these cities have achieved high $C I$ allowing them to be included in Table 2. That is the case for cities in cluster 3 and 4, mainly. It is an interesting, noteworthy result, since it can be an information source to identify deficiencies on local level of scientific agents to improve RIS. Clearly, this is not the case for cities as Rio Claro, Lagoa Santa and Santa Maria since the firms located in those cities can access scientific agents in close interactive centers (São Carlos and Campinas for Rio Claro, Belo Horizonte for Lagoa Santa and Porto Alegre for Santa Maria), but it can be the case for cities in less favored regions, as those in Northeast region. 
Figure 4: Clusters for Cities, 2008.

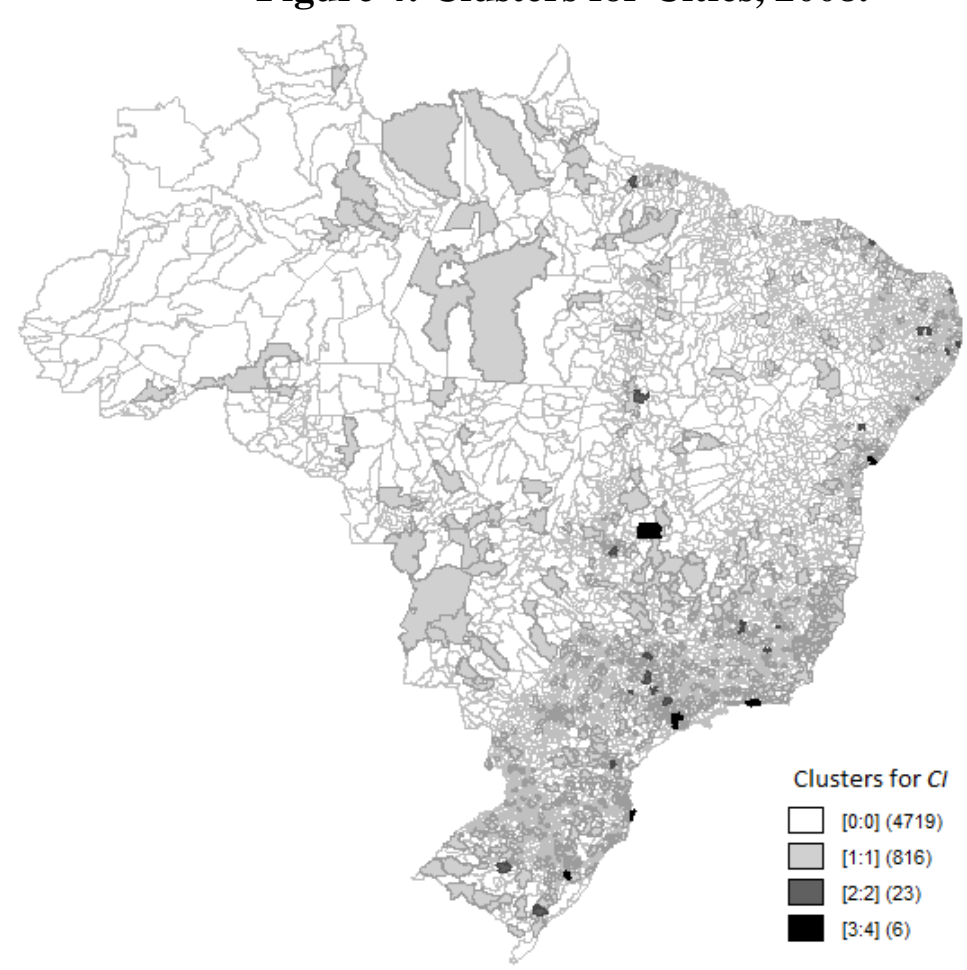

Source: Own elaboration.

\section{CONCLUSION}

Departing from Regional Innovation Systems and university-firms interactions frameworks this article investigated the innovation systems' capabilities in terms of external interactions among scientific and innovative agents. The DGP database permits analyses based in knowledge flow regarding Brazilians regions.

In a general view, cities in the Southeast Region - plus Brasilia, the national capital - have liquid positive knowledge flow against the Northeast Region. It indicates the importance of universities and research institutes in this federative region to provide knowledge. Besides, there is a considerable number of interactions within cities, highlighting the importance of proximity on U-I interactions. In a nutshell, these results points out to an uneven distribution among regions and cities regarding the RIS capacity to attract interactions from outside.

There is, however, a less concentration than one identified in previous articles, although not concerned with our purpose, which could be seen in the scale analysis interaction flow maps - and relative analysis - based on the Coefficient of Interactivity. Comparing these two essays, we may observe a significant correlation between scale and efficiency of interactions with the emergence of interesting RIS in South and Northeast regions. More deeply, when observing the efficiency based on CI, emerge the importance of three cities outside the Southeast-Brasilia axis: Florianopolis, Porto Alegre and Salvador.

Besides that, an expressive number of cities in cluster 3 (and cluster 4 too) present itself as potential strong RIS at least in local level. Most of these cities has relevant values of $C I_{f}$, which indicates an interesting number of interactive firms. This may be signaling the relevance of a more precise observation in these locations, trying to understand the positioning of these interactive agents and ways to provide better 
conditions of interaction, always looking for a better environment for regional development.

It is worth to note that these results are preliminary and should be studied carefully. The adequacy of the data to the most recent census and the use of another scientific, technological and economic variable must also be incorporated to the robustness of the findings. Anyway, we understand that using U-I interaction flows to measure innovative capacity of regions may be an interesting methodology that should be better developed.

\section{REFERENCES}

ALBUQUERQUE, E. M.; SIMÕES, R.; BAESSA, A.; CAMPOLINA, B.; SILVA, L. A. A distribuição espacial da produção científica e tecnológica brasileira: uma descrição de estatísticas de produção local de patentes e artigos científicos. Revista Brasileira de Inovação, Rio de Janeiro, v. 1, n. 2, p. 225- 251, 2002.

BOYANDIN, I., BERTINI, E., LALANNE, D. Visualizing the World's Refugee Data with JFlowMap. Poster Abstracts at Eurographics/IEEE-VGTC Symposium on Visualization, 2010.

BRENNER, T. Industrial Districts: A Typology from an Evolutionary Perspective. Danish Research Unit for Industrial Dynamics 3, Vol I: Conference on The Learning Economy- Firms, Regions and Nation Specif Institutions, Denmark, 2001.

CALIARI, T., RAPINI, M. S. (2016) Diferenciais da Distância Geográfica na Interação Universidade-Empresa no Brasil: um foco sobre as características dos agentes e das interações. Nova Economia, Belo Horizonte, forthcoming.

CASAlI, G. F. R.; SILVA, O. M.; CARVALHO, F. M.A. Sistema Regional de Inovação: estudo das regiões brasileiras. Revista de Economia Contemporânea, Rio de Janeiro, v. 14, n. 3, p. 515-550, set./dez. 2010.

COOKE, P. (1998). Introduction: Origins of the concept. In Braczyk, H., Cooke, P., \&Hidernreich, M., editors, Regional Innovation Systems, pages 2-25. UCL Press, London.

FLORIDA, R. Toward the Learning Region. Futures, v 27, nº 5, pp. 527-536. 1995.

FRITSCH, M. (2002) Measuring the quality of regional innovation systems: a knowledge production function approach. International Regional Science Review 25, 1: 86-101 (January 2002).

DINIZ C. C.; GONCALVES, E. Knowledge economy and regional development in Brazil. In: The third Congress on proximity. Paris. Les troisièmes journées de la proximité, 2001.

FELDMAN, M. The Geography of Innovation. Netherlands:Kluwer Academic Publishers. 1994.

GARCIA, R., ARAÚJO, V., MASCARINI, S., SANTOS, E. (2014). Efeitos da Qualidade da Pesquisa Acadêmica sobre a Distância Geográfica das Interações Universidade-Empresa. Estudos Econômicos, São Paulo, vol. 44, n.1, p. 105-132, jan.-mar. 2014.

GONÇALVEZ, E.; FAJARDO, B.A.G.E. A influência da proximidade tecnológica e geográfica sobre a inovação regional no Brasil. Revista de Economia Contemporânea, Rio de Janeiro, v. 15, n. 1, p. 112-142, jan-abr/2011.

GRANOVETER, Mark. Economic Action and Social Structure: the problem of embeddedness. Ajs, Chicago, v. 91, n. 3, p.481-510, Nov. 1985.

HOLTEN D., VAN WIJK J. J.: Force-Directed edge bundling for graph visualization. Computer Graphics Forum 28, 3 (2009), 983-990. 
KLEVORICK, A. K.; LEVIN, R.; NELSON, R.; WINTER, S. On the sources and significance of inter-industry differences in technological opportunities. Research Policy, v.24, n.2, March, 1995, p.185-205.

JAFFE, A. B. (1989) Real Effects of Academic Research. The American Economic Review, v.79, 5, p. 957-970, December, 1989.

JAFFE, A. B.; TRAJTENBERG, M; HENDERSON, R. (1993) Geographic Localization of knowledge spillovers as evidence by patent citation The Quartely Journal of Economics, v. 108, n.3, p. 577-598, August, 1993.

LAURSEN, K.; REICHSTEIN, T.; SALTERS, A. (2011). Exploring the effect of Geographical Proximity and University Quality on University-Industry Collaboration in the United Kingdom. Regional Studies 45(4), p. 507-523.

LENGYEL, B., LEYDESDORFF, L. (2011) Regional innovation systems in Hungary: The failing synergy at the national level. Regional Studies, Vol 45, issue 5, may 2011, 677-693.

LEYDESDORFF, L., FRITSCH, M. (2006) Measuring the Knowledge Base of Regional Innovation Systems in Germany in terms of a Triple Helix dynamics. Research Policy, Volume 35, Issue 10, December 2006, Pages 1538-1553.

MAIA, M. G. S. F. A (2005) Integração Universidade/Empresa como Fator De Desenvolvimento Regional: Um Estudo da Região Metropolitana de Salvador. Tese de Doutorado, Universidade de Barcelona, Barcelona, 252 p. 2005.

MANSFIELD, E., (1995). Academic research underlying industrial innovations: sources, characteristics, and financing. Rev. Econ. Stat., Vol. 77, No. 1, Feb., 1995, 55-65.

MARIANI, M., (2004). What determines technological hits? Geography versus firm competencies. Research Policy 33, 1565-1582.

MASKELL, P; MALMBERG, A. Localized learning and industrial competitiveness. Cambridge Journal of Economics, v.23, pp.167-185, 1999.

MYTELKA, L.; FARINELLI, F. From Local clusters to innovation systems. In: CASSIOLATO, J. E., LASTRES, H. M., MACIEL, M. L. Systems of innovation and development: evidence from Brazil. Cheltenham, UK; Northhampton, USA: E. Elgar, 2003. p 249-272.

MingOTI, S. A. Análise de Dados Através de Métodos de Estatística Multivariada: Uma Abordagem Aplicada. Belo Horizonte: UFMG, 2005.

NARIN, F., HAMILTON, K., OLIVASTRO, D. The increasing linkage between US technology and public science. Research Policy 26, 317-330, 1997.

OINAS, P. e MALECKI, E. (1999). Spatial innovation systems. In Malecki, E. \& Oinas, P., editors, Making Connections: Technological learning and regional economic change, pages 7-33. Ashgate, Aldershot (UK).

PAVITT, K. (1998) The Social Shaping of the national science base. Research Policy, v.27, n.8, p.793-805, 1998.

ROSENBERG, N.Scientific instrumentation and univeristy research.? Research Policy, v.21, n.4, August 1992, p.381-390.

SANTOS, U. P., CALIARI, T. Distribuição Espacial das Estruturas de Apoio às Atividades Tecnológicas no Brasil: Uma Análise Multivariada para as Cinquenta Maiores Microrregiões do País. EconomiA, Brasília(DF), v.13, n.3b, p.759-783, set/dez 2012.

SANTOS, U. P.. Ambiente institucional e inovação na siderurgia de Minas Gerais. 1. ed. Fortaleza: Banco do Nordeste, 2012. 153p 